\title{
Nohut ununun tavuk köfte üretiminde kullanımı
}

\section{Osman KILINÇÇEKER iD 1}

${ }^{1}$ Adıyaman Üniversitesi, Teknik Bilimler Meslek Yüksekokulu, Gıda İşleme Bölümü, Kampüs-Adıyaman

\section{Öz}

Bu çalışmada: nohut unu ve buğday unundan beş farklı oranlarda hazırlanan karışımların tavuk köftelere $\% \quad 7 \quad$ seviyesinde ilavesinin bazı özellikler üzerine etkileri araştırılmıştır. Çalışmada kızartılmamış köftelerin renk değerleri belirlenirken, $180{ }^{\circ} C^{\prime}$ de 6 d kızartılan örneklerin verim, çap azalması, renk, nem tutma oranları, yağ emme oranları ve duyusal nitelikleri saptanmıştır. Sonuç olarak; nohut ununun kızartılmamış örneklerde $L^{*}$ ve $a^{*}$ değerlerini etkilemediği, $b^{*}$ değerlerini ise arttırdığı anlaşılmıştır. Kızartılan örneklerin verim ve çap değerlerini yüksek oranda katıldığında arttırırken, renk değerlerini etkilemediği tespit edilmiştir. Benzer şekilde yüksek oranda kullanımında nem tutma oranlarını artırmıştır. Duyusal özelliklerden ise; yalnızca tat üzerinde etkili olmuş, düşük oranda kullanımda puanları artırmıştır. Bütün sonuçlara bağlı olarak; tavuk köfte yapımında $1: 1$ ve $2: 1$ oranlarındaki nohut unu: buğday unu karışımlarından birini veya \% 100 nohut ununu eklemenin tavsiye edilebileceği anlaşılmıştır.

Anahtar kelimeler: Nohut unu, buğday unu, tavuk köfte, kızartma

\section{Usage of chickpea flour in production of chicken meatball}

\begin{abstract}
In this study; the effects on some properties of addition at $7 \%$ ratio of mixes that prepared with five different proportions of chickpea flour and wheat flour in chicken meatballs were investigated. While colour values were measured in raw meatballs; yield, diameter reduction, colour, moisture retention rates, oil absorption rates and sensory qualities were determined in samples fried at $180{ }^{\circ} \mathrm{C}$ for $6 \mathrm{~min}$. As a result; it has been understood that chickpea flour did not affect $L^{*}$ and $a^{*}$ values in raw samples and increased $b^{*}$ values. When it added in high ratios; it has been observed that the yields and diameters of fried samples increased but did not affect the colour values. Similarly, it increased moisture retention rates in high usage amounts. It was only effective on taste as sensory and it increased the scores in low usage. Based on all the results; it was understood that it may be advisable to add $1: 1$ and 2:1 chickpea flour: wheat flour or $100 \%$ chickpea flour to chicken meatballs.
\end{abstract}

Key words: Chickpea flour, wheat flour, chicken meatball, frying 


\section{Giriş}

Tavuk eti besin değerinin yanı sıra ucuz olması nedeniyle de tüketici tercihinin yüksek olduğu bir gıda kaynağıdır. Kolay bulunmasının yanı sıra, kaliteli proteine sahip olması bu tercihi etkileyen önemli faktörlerden birisidir. Ayrıca kalori değerlerinin kırmızı etlere göre daha düşük olması bașka bir avantajıdır denilebilir (Barbut, 2012; Dokuzlu ve ark., 2013) .

$\mathrm{Bu}$ sebeplerle sektörde faaliyet gösteren işletmeler bu grubun işlenmesini ve tercih edilebilirliğini artırabilecek teknikleri ve malzemeleri belirleyerek, uygulamaya çalışmaktadırlar. Bilim insanları bilinçli beslenmenin arttığı günümüz toplumunda ihtiyaca cevap verebilecek ürünleri ortaya koyarken, son ürün kalitesi yüksek olan alternatifler sunmaya çalışmaktadırlar (Dokuzlu ve ark., 2013; Kılınççeker ve Kırpık, 2019).

Tavuk etleri bahsedilen sebeplerden dolayı en fazla araştırılan materyallerden bir tanesidir. Çoğunlukla ucuz olan ve besin değeri yüksek bir kaynaktır. Tavuk etlerinin fileto, pane veya köfte şeklinde birçok çeșidi olup, bunların üretimi sırasında yapısal özelliklerine bağlı olarak parçalanma, dağılma ve kolay okside olma gibi problemler ortaya çıkabilmektedir. Sonuç olarak; ekonomik kayıp meydana gelmektedir (Cava ve ark., 2012; Dokuzlu ve ark., 2013; Kılınççeker ve ark., 2015).

Belirtilen hataları elemine edebilmek için üreticiler; gamlar, nişastalar veya proteinler gibi değişik yapı düzenleyicileri uygulayabilirlerken, organik asit gibi çeşitli koruyucuları da bileşime katabilmekte, ya da bunların birkaçını yapılarında bulundurabilen çeşitli bitkisel unları ilave ederek son üründe fayda sağlayabilmektedirler (Petracci ve ark., 2013; Demirci ve ark., 2014, Kılınççeker ve Karahan, 2019a). Bahsedilen unlara buğday unu, mısır unu veya kinoa unu örnek olarak verilebilirken, son zamanlarda gündemde olan çeşitlerden bir tanesi de nohut unudur.

Nohut; kuru madde bazında yaklaşılk olarak \% 24 protein, \% 55 karbonhidrat, \% 4 mineral madde, \% 6 yağ ve \% 10 diyet lif içeriğine sahiptir. Ayrıca vitamin bakımından oldukça zengindir. Özellikle yapısındaki protein ve lifler nedeni ile su tutma gibi farklı fonksiyonel özellikler sergileyebilmektedir. Bu nedenle farklı gıdaların bileşiminde besin içeriğini düzenlemek, tekstürü geliştirmek veya raf ömrünü arttırmak gibi amaçlar için kullanımları mevcut iken, tavuk eti ile ilgili çalışmaların oldukça az olduğu gözlenmiştir (Kılınççeker ve ark., 2015; Sayar ve Karataş, 2017).

Anlatılanlara bağlı olarak nohut ununun tavuk köfte yapımında kullanımında bazı faydalar sağlayabileceği düşünülmüştür. Çalışmamızda; nohut unu ile buğday ununun farklı oranlarda karışımları hazırlanarak tavuk etine katıldığında, sebep olabileceği yararlar göz önüne serilerek, sektör için farklı alternatifler sunulmaya çalışılmıștır.

\section{Materyal ve Yöntem}

Araştırma kullanılan nohut unu piyasadan satın alınmıştır. Tavuk gögüs eti ve diğer malzemeler Adıyaman'daki yerel işletmelerden temin edilmiştir. Taze olarak alınan etler küçük parçalara bölündükten sonra Tefal marka kıyma makinasının 3' lük aynasında kıyılarak köfte yapımında kullanılmışlardır. Derin yağda kızartma işlemi için mini kızartma makinası (Tefal) ve Yudum marka (Türkiye) ayçiçek yağı kullanılmıştır. Başlangıç aşamasında buğday unu ve nohut unundan; \% 100 buğday unu (kontrol), 1:2 nohut unu:buğday unu, 1:1 nohut unu:buğday unu, 2:1 nohut unu:buğday unu ve \% 100 nohut unu olacak şekilde karışımlar oluşturulmuştur. Bunlardan da alınarak \% 90.5 kıyılmış et $+\% 7$ un karışımı $+\% 1$ ayçiçek yağı $+\%$ 1.5 tuz olacak şekilde asıl örnekler hazırlanmıştır. Örnekler iyice yoğurulduktan sonra $20 \mathrm{~d} 4{ }^{\circ} \mathrm{C}^{\prime} \mathrm{de}$ dinlendirilmiş sonra $19 \mathrm{~g}$ ağırlı̆̆ında ve $31-32 \mathrm{~mm}$ çapında yuvarlak köfteler hazırlanmıştır. Her karışımdan 4 köfte alınarak $180 \quad{ }^{\circ} C^{\prime}$ de $\quad 6 \quad$ d kızartılmışlardır. Bu süreçte ham ve kızarmış köftelerde renk kriterleri olan $L^{*}$ (açıklık), $a^{*}$ (kırmızılık) ve $b^{*}$ (sarılık) değerleri kolorimetre (Konica Minolta, Inc., Osaka, Japan) kullanımı ile, her bir köftenin üç farklı noktasında, ölçülmüştür. Kızartma verimi; hassas terazi, çap değişimleri ise dijital kumpas yardımı ile Kurt ve Kılınççeker (2012)'in aşağıdaki eşitlik 1 ve 2'de belirttiği formüllere göre hesaplanmıștır. Kızarmamıș örneklerde ağırlık ve çaplar ölçüldükten sonra, kızartma işleminden 1-1.5 d sonra tekrar ağırlık ve çaplar belirlenmiştir. Çap ölçümleri her bir köftede 3 farklı noktadan olacak şekilde gerçekleştirilmiştir.

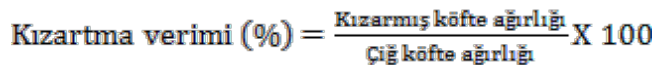

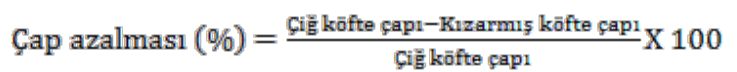

Köftelerdeki nem oranları; kızartma öncesi ve kızartma sonrasında, $105^{\circ} \mathrm{C}^{\prime}$ de etüvde sabit ağırlığa 
gelene kadar kurutularak, yağ miktarları ise; yine kızartma öncesi ve sonrası, çözücü olarak hegzanın kullanıldığı sokshelet ekstraksiyon yöntemi ile belirlenmiştir (Anonim, 2002). Elde edilen sonuçlara bağlı olarak nem tutma ve yağ emme oranları aşağıdaki denklemlere göre hesaplanmıştır.

Nem tutma $(\%)=\frac{\text { Kızarmıs̆ kōftedeki nem }(\%)}{\text { Çĭ̈ köftedeki nem }(\%)} x$ verím

Yağ emilim (\%) = kızarmış köftedeki yağ (\%) - çiğ köftedeki yağ (\%)

Yürütülen çalışmanın son analizi olan duyusal kalite için her bir örnekten 6'şar köfte hazırlanarak 180 ${ }^{\circ} C^{\prime}$ de 6 d kızartılmıştır. Yaklaşık 1 d sonra, kısa bir eğitime tabi tutulmuş 10 kişilik gıda işleme bölümü öğrencisine, Gökalp ve ark., (1999)' nın belirttiği gibi, hedonik beğeni derecelendirme yöntemi doğrultusunda 1 (aşırı derecede hoşlanmamak) - 9 (aşırı derecede hoşlanmak) puanlar arasında puanlama yaptırılmıştır. Denemeler iki tekerrür ve üç paralel olarak sürdürülmüştür. İstatistiksel analizler için; SPSS 16.0 (2007) istatistik paket programı kullanılmıştır. Sonuçlar; varyans analizine tabii tutulup, istatistiksel olarak önemli çlkan ortalamalara $\mathrm{P}<0.01$ ve $\mathrm{P}<0.05$ düzeyinde Duncan çoklu karşılaştırma testi uygulanmış, değerler ortalama \pm standart sapma olarak sunulmuştur (SPSS, CHICAGO, IL, USA).

\section{Bulgular ve Tartışma}

Marketlerde ve restoranlarda satışı yapılan köfte gibi gıdaların en dikkat çekici özelliklerinden bir tanesi renktir. Genel olarak formülasyonlarda kullanılan malzemelerin doğal renk maddelerinden etkilenen bu özellik, satıșta ve tüketimde tüketici üzerinde kuvvetli etkiye sahiptir. Dolayısı ile pişmiş ürünlerde olduğu gibi o ürünlerin çiğ veya yarı pişmiş olanlarında da renk kriterlerinin saptanması önerilmektedir (Kılınççeker ve Karahan, 2019a). Çalışmada kullanılan kızartılmamış örneklerin renk değerleri Çizelge 1'de verilmiştir. Çizelgeden de anlaşılabileceği gibi çiğ örneklerin $L^{*}$ ve $a^{*}$ değerleri üzerinde nohut unu herhangi bir etkiye sahip olmazken ( $\mathrm{P}>0.05), b^{*}$ değerlerini artırdığı ve \% 100 $\mathrm{N}$ içeren örneklerin 22.05 olarak en yüksek $b^{*}$ değerine sahip olduğu söylenebilir $(\mathrm{P}<0.01)$. Benzer şekilde; Kılınççeker ve Karahan (2019a)' in keçiboynuzu unu katarak ürettikleri tavuk köftelerde pişmemiş örneklerin renk özelliklerinin etkilenebildiği vurgulanmıştır. Ortaya çıkan farklılıkların liflerin ve keçiboynuzu ununun doğal renk maddelerinden kaynaklandığı belirtilmiştir. Ayrıca aynı araştırmacıların başka bir çalışmalarında; tef unu katarak hazırlanan balık köftelerde $L^{*}$ ve $a^{*}$ değerlerinin değişmediği $b^{*}$ değerlerinin ise düşüş gösterdiği bulunmuştur. Bu durumu tefin yapısındaki doğal renk maddelerine bağlamışlardır (Kılınççeker ve Karahan, 2019b). Bizim çalışmamızda da yapılan analizlerde buğday ununun renk indeksler $L^{*}=91.06, a^{*}=-0.37, b^{*}=$ 10.86 olarak belirlenirken, nohut unu için bu değerler $L^{*}=89.13, a^{*}=-2.19$ ve $b^{*}=19.30$ olarak ölçülmüştür. Yani nohut ununda özellikle sarı renk $\left(b^{*}\right)$ oranının oldukça yüksek olduğu anlaşılmıştır. Dolayısı ile nohut ununun sahip olduğu bu sonucun, oransal miktarının artışı ile kızartılmamış köftelerin $b^{*} \quad$ değerlerinde yükselmeye sebep olduğu düşünülmektedir.

Çizelge 1. Nohut ununun kızartılmamış köftelerdeki renk değerleri üzerine etkisi

\begin{tabular}{cccc}
\hline Bileşen & $L^{*}$ & $a^{*}$ & $b^{*}$ \\
\hline Kontrol & $67.50 \pm 2.32^{\mathrm{a}}$ & $4.79 \pm 0.02^{\mathrm{a}}$ & $16.55 \pm 0.73^{\mathrm{d}}$ \\
$1: 2 \mathrm{~N}: \mathrm{B}$ & $65.15 \pm 1.80^{\mathrm{a}}$ & $4.01 \pm 0.08^{\mathrm{a}}$ & $17.56 \pm 0.20^{\mathrm{cd}}$ \\
$1: 1 \mathrm{~N}: \mathrm{B}$ & $63.87 \pm 2.28^{\mathrm{a}}$ & $3.61 \pm 0.48^{\mathrm{a}}$ & $18.40 \pm 0.66^{\mathrm{bc}}$ \\
$2: 1 \mathrm{~N}: \mathrm{B}$ & $65.62 \pm 0.07^{\mathrm{a}}$ & $4.07 \pm 0.52^{\mathrm{a}}$ & $19.53 \pm 0.44^{\mathrm{b}}$ \\
$\% 100 \mathrm{~N}$ & $63.79 \pm 1.51^{\mathrm{a}}$ & $4.59 \pm 0.50^{\mathrm{a}}$ & $22.05 \pm 0.35^{\mathrm{a}}$ \\
\hline
\end{tabular}

$\mathrm{N}$ :nohut unu; B:Buğday unu, ${ }^{\mathrm{a}-\mathrm{d}}$ :her bir sütundaki istatistiki farklılığı göstermektedir $(\mathrm{P}<0.05)$

Kızartma gibi yüksek ısıda pişirmede et ürünlerinde görülen en önemli değişimler dağılma, şekil bozukluğu, çap değişimi, verim veya renkteki farklılaşmalardır. Genellikle yapısal dağılma ve kızartma sonrası verim oranları ürünün satışı esnasındaki ağırlığı ve ambalajlama işlemleri üzerinde etkiye sahiptirler. Kızartma sonrası oluşan renk ise; ürünün tüketimi esnasında duyusal beğeniyi etkileyen en önemli dış özelliktir (Demirci ve ark., 2014; Kılınççeker ve Karahan, 2019b). Bizim çalışmamızda bahsedilen kriterlere ait sonuçlar Çizelge 2'de gösterilmiştir. Bu çizelgeye bakıldığ zaman nohut unu katmanın kızarmış köftelerdeki verimi artırırken, çaplardaki azalma oranını düşürdüğü, hatta (-) işaretlerde de anlaşılacağı gibi çaplarda artışa sebep olduğu söylenebilir $(\mathrm{P}<0.05)$. Buna karşın kızartma sonrası renk değerleri üzerinde bir etkiye sahip olmamıştır ( $\mathrm{P}>0.05)$. En yüksek verim oranları $\% 81.23$ ve $\% 80.77$ olarak $2: 1$ $\mathrm{N}: \mathrm{B}$ ve $\% \quad 100 \mathrm{~N}$ ile hazırlanan köftelerde hesaplanmıştır. En düşük çap azalma oranları ise \% $1.59, \%-3.74$ ve $\%-3.11$ olarak sirasiyla $1: 1,2: 1$ ve $\% 100 \mathrm{~N}$ içeren örneklerde ortaya çıkmıştır. Yani bu örneklerde çap azalmamış, aksine (-) işaretinden de 
anlaşıldığı üzere artmıştır. Ayrıca $L^{*}$ değerlerinin 55.88-59.81, $a^{*}$ değerlerinin 9.73-12.31 ve $b^{*}$ değerlerinin ise 37.71-39.48 aralığında olduğu anlaşılmaktadır. Yapılan literatür araştırmalarında Kılınççeker ve Karahan (2019a)'ın tavuk köftelere keçi boynuzu unu kattıklarında kızartma sonrası verimi artırdıkları belirlenmiştir. Ayrıca, Soltanizadeh ve Ghiasi-Esfehani (2014) sığır etinde yaptıkları köftelere Aloe vera kattıklarında çap azalmasını düşürdüklerini gözlemişlerdir. Mansour ve Khalil (1997)'de et köftelere buğday lifi eklediklerinde çap küçülmesini azalttıklarını saptamışlardır. Bütün araştırmacılar bu bileșenlerin hidrokolloid gibi davranarak kayıpları azalttıklarını ve şekli koruduklarını vurgulamışlardır. Bu araştırmalarda bizim verilerimizi destekler niteliktedir. Bununla birlikte, yaptığımız çalışmada özellikle verim üzerinde etkili olacağını düşündüğümüz su absorpsiyon oranları buğday unu için \% 67.55, nohut unu için ise \% 106.50 olarak bulunmuştur. $\mathrm{Bu}$ sonuçları da göz önünde bulundurarak nohut ununun yapısındaki protein ve lif gibi maddelerin nem kaybını azaltarak verimde artışa sebep oldukları, yapılarındaki bağların kuvvetine bağlı olarak, şişme özelliklerinden dolayı da, çapta artışa sebep oldukları düşünülmektedir.

Çizelge 2. Nohut ununun kızarmış köftelerdeki verim, çap azalması ve renk değerleri üzerine etkisi

\begin{tabular}{|c|c|c|c|c|c|}
\hline Bileșen & Verim (\%) & Çap azalması (\%) & $L^{*}$ & $a^{*}$ & $b^{*}$ \\
\hline Kontrol & $78.89 \pm 0.94^{\mathrm{ab}}$ & $4.05 \pm 1.75^{\mathrm{a}}$ & $55.88 \pm 0.74^{a}$ & $11.34 \pm 0.97^{a}$ & $37.71 \pm 0.49^{a}$ \\
\hline $1: 2 \mathrm{~N}: \mathrm{B}$ & $76.63 \pm 1.96^{b}$ & $-0.36 \pm 0.94^{\mathrm{ab}}$ & $57.87 \pm 0.81^{\mathrm{a}}$ & $12.31 \pm 0.44^{\mathrm{a}}$ & $39.48 \pm 0.23^{a}$ \\
\hline $1: 1 \mathrm{~N}: \mathrm{B}$ & $76.60 \pm 1.41^{b}$ & $-1.59 \pm 1.20^{\mathrm{b}}$ & $58.06 \pm 0.41^{\mathrm{a}}$ & $10.89 \pm 1.24^{\mathrm{a}}$ & $38.92 \pm 1.25^{a}$ \\
\hline $2: 1 \mathrm{~N}: \mathrm{B}$ & $81.23 \pm 0.20^{\mathrm{a}}$ & $-3.74 \pm 3.47^{b}$ & $57.44 \pm 2.42^{\mathrm{a}}$ & $10.77 \pm 1.02^{\mathrm{a}}$ & $38.12 \pm 0.83^{a}$ \\
\hline$\% 100 \mathrm{~N}$ & $80.77 \pm 1.34^{a}$ & $-3.11 \pm 1.25^{b}$ & $59.81 \pm 2.03^{a}$ & $9.73 \pm 1.75^{\mathrm{a}}$ & $38.68 \pm 0.88$ \\
\hline
\end{tabular}

$\mathrm{N}:$ nohut unu; B:Buğday unu, ${ }^{\mathrm{a}-\mathrm{b}}$ :her bir sütundaki istatistiki farklılığı göstermektedir $(\mathrm{P}<0.05)$.

Şekil 1'de sunulan nem tutma ve yağ emme miktarlarına bakıldığında nem tutma oranlarındaki farklılığın $\quad \mathrm{P}<0.01$ düzeyinde önemli olduğu anlaşllırken; yağ emme oranlarında bir farklılık gözlenmemiştir $(\mathrm{P}>0.05)$. Nem tutma oranları dalgalı bir değişim sergilemiş olup, özellikle $\% 70.52$ değeri ile 2:1 N:B karışımı kullanmanın daha avantajlı olacağı anlaşılmıştır. Yağ emme oranlarının ise \% 2.48 ile \% 3.14 aralı̆̆ında değişim gösterdiği anlaşılmaktadır. Sonuçlarımız Kılınççeker ve Karahan (2019a)'ın keçi boynuzu unu ile hazırladıkları tavuk köftelerdeki nem tutma değerlerindeki artışla benzeşmektedir. Ayrıca,
Kılınççeker ve Karahan (2019b) tarafından tef unu kullanılarak üretilen balık köftelerde bu unun miktar artışı ile nem tutmanın ve yağ emmenin düzensiz bir değişim gösterdiği, ancak istatistiksel olarak farklılığın oluşmadığı değerler ile de benzerlik arz etmektedir. $\mathrm{Bu}$ çalışmalarda da belirtildiği gibi özellikle nohut ununun yapısındaki protein, nişasta ve lifler hidrofilik özellikte olduklarından su absorpsiyon oranını artırarak kızartma esnasında yüksek miktarda suyu yapıda bağlamışlardır. Sonuç olarak, un karışımlarında nohut unu miktarı arttıkça nem tutma oranı da çoğunlukla artış göstermiştir denilebilir.

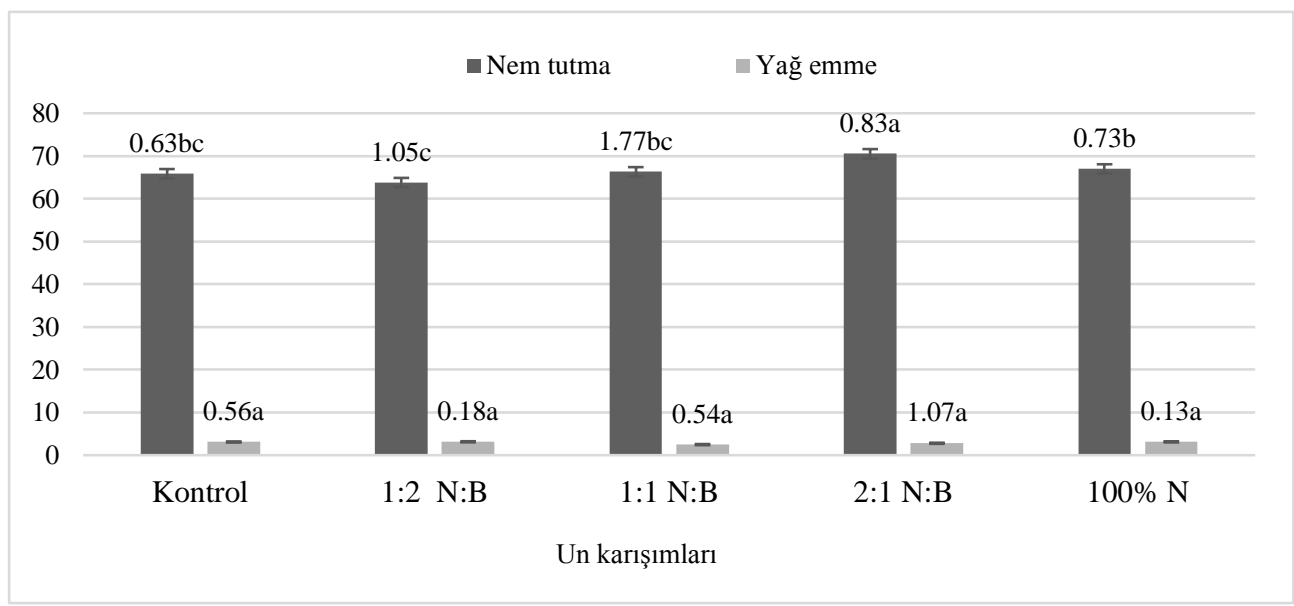

Şekil 1. Nohut ununun kızarmış köftelerdeki nem tutma ve yağ emme oranları üzerine etkisi (\%). 
En son analiz grubu olan duyusal kalite puanlarına ait ortalamalar Çizelge 3' te sunulmuştur. Bu çizelgeden anlaşılacağı üzere, nohut unu katma görünüş, renk, koku ve tekstür puanları üzerinde herhangi etki oluşturmazken $(\mathrm{P}>0.05)$, tat puanlarını $\mathrm{P}<0.05$ düzeyinde etkilemiştir. Özellikle nohut ununun düşük seviyelerde kullanımında yüksek puanlar alındığı, en yüksek değerlerin 7.47 ve 7.65 olarak 1:2 ile 1:1 oranında $\mathrm{N}: \mathrm{B}$ karıșımı ile hazırlanan köftelerde olduğu belirlenmiştir. Başka çalışmalarda tavuk veya balık etlerine farklı unları katarak yapılan denemelerde birçok duyusal özelliğin istatistiksel olarak farklılık yaratmadığ ancak bu unların glüten içermemeleri, kaliteli proteine sahip olmaları ve yapılarındaki diyet özellikteki liflerden dolayı kullanımlarının tavsiye edilebileceği vurgulanmıştır (Kılınççeker ve Kırpık, 2019; Kılınççeker ve Karahan, 2019b). Çalışmamızdaki sonuçlar bahsedilen araştırmalarla benzerlik arz etmektedir.

Çizelge 3. Nohut ununun kızarmış köftelerdeki duyusal değerler üzerine etkisi

\begin{tabular}{|c|c|c|c|c|c|}
\hline Bileşen & Görünüș & Renk & Koku & Tat & Tekstür \\
\hline Kontrol & $7.10 \pm 0.14^{a}$ & $7.55 \pm 0.07^{a}$ & $7.85 \pm 0.92^{\mathrm{a}}$ & $7.32 \pm 0.11^{\mathrm{ab}}$ & $8.27 \pm 0.67^{a}$ \\
\hline $1: 2 \mathrm{~N}: \mathrm{B}$ & $7.12 \pm 0.18^{a}$ & $7.72 \pm 0.74^{a}$ & $7.57 \pm 0.25^{a}$ & $7.47 \pm 0.32^{\mathrm{a}}$ & $8.02 \pm 0.32^{\mathrm{a}}$ \\
\hline $1: 1 \mathrm{~N}: \mathrm{B}$ & $7.92 \pm 0.46^{\mathrm{a}}$ & $8.37 \pm 0.53^{a}$ & $7.52 \pm 1.02^{a}$ & $7.65 \pm 0.21^{\mathrm{a}}$ & $7.92 \pm 0.95^{a}$ \\
\hline $2: 1 \mathrm{~N}: \mathrm{B}$ & $6.92 \pm 0.46^{a}$ & $7.55 \pm 0.07$ a & $7.10 \pm 0.14^{a}$ & $7.00 \pm 0.00^{\mathrm{bc}}$ & $7.65 \pm 0.21^{a}$ \\
\hline$\% 100 \mathrm{~N}$ & $7.72 \pm 0.67 a$ & $7.62 \pm 0.88^{a}$ & $7.10 \pm 0.14^{\mathrm{a}}$ & $6.77 \pm 0.03^{c}$ & $6.97 \pm 0.32^{\mathrm{a}}$ \\
\hline
\end{tabular}

$\mathrm{N}$ :nohut unu; B:Buğday unu, ${ }^{\text {a-c }}$ :her bir sütundaki istatistiki farklılığı göstermektedir $(\mathrm{P}<0.05)$.

\section{Sonuç}

Çalışmadan elde edilen verilere göre; nohut ununun tavuk köftelerde bazı özellikleri etkileyebileceği tespit edilmiştir. Kızartılmamış örneklerde sarılık $\left(b^{*}\right)$ değerini artırabilecek bir malzeme olabileceği anlaşılırken, kızarmış örneklerde verimi ve çapları artırabileceği tespit edilmiştir. Kızarmış ürünler için önemli olan nem tutma oranını artırabileceği, duyusal özelliklerden ise özellikle düșük seviyelerde kullanıldığında tat üzerinde olumlu etkisinin olabileceği anlaşılmıştır. Sonuç olarak; önceki araştırmalarda bahsedilenler ve çalışmamızda ortaya çlkan sonuçlar göz önünde bulundurulduğunda; bu tarz köftelerin yapımında ya da diğer gıda üretimlerinde nohut unu kullanımının araștırılmasının önemli olduğu, özellikle buğday unu gibi malzemelerle karışım olarak kullanılacak ise 1:1 veya 2:1 nohut unu: buğday unu karışımlarından birini ya da sadece nohut unu kullanımının tavsiye edilebileceği anlaşılmıştır.

\section{Teşekkürler}

$\mathrm{Bu}$ çalışmanın yürütülmesi esnasında teknik destek sağlayan Selahattin KARADERE'ye teşekkür ederim.

\section{Kaynaklar}

Anonim, (2002). Offical Methods of Analysis (17th ed.). Association of official analytical chemists, Washington, DC.

Barbut, S., (2012). Convenience breaded poultry meat products- New developments. Trends in Food sciences and Technology, 26(1), 14-20.
Cava, R., Ladero-Cantero, L., \& Ramirez, V.R., (2012). Assessment of different dietary fibers (tomato fiber, beet root fiber, and inulin) for the manufacture of chopped cooked chicken products, Journal of Food Sciences, 77(4), 346-352.

Demirci, Z.O., Yılmaz, I., \& Demirci, A.Ş., (2014). Effects of xanthan, guar, carrageenan, and locust bean gum addition on physical, chemical, and sensory properties of meatballs, Journal of Food Sciences and Technology, 51(1), 936-942.

Dokuzlu, S., Barış, O., Hecer, C., \& Güldaş, M., (2013). Türkiye'de tavuk eti tüketim alışkanlıkları ve marka tercihleri. Uludă̆ Üniversitesi Ziraat Fakültesi Dergisi, 27(2), 83-92.

Gökalp, H.Y., Kaya, M., Tülek, Y., \& Zorba, Ö., (1999). Et ve ürünlerinde kalite kontrolü ve laboratuvar uygulama klavuzu. Atatürk Üniversitesi Ziraat Fakültesi, Yay No, 318, Erzurum, Turkey.

Kılınççeker, O., \& Karahan, A.M., (2019a). Keçiboynuzu (Ceratonia siliqua L.) ununun tavuk köfte üretiminde kullanım olanakları. Iğdır Üniversitesi Fen Bilimleri Enstitüsü Dergisi, 9(2), 862-869.

Kılınççeker, O., \& Karahan, A.M., (2019b). Tef (Eragrostic Tef) tohumu ununun balı köfte üretiminde kullanım olanakları. Adyütayam Dergisi, 7(2), 2735.

Kılınççeker, O., \& Kırpık, M., (2019). Keten tohumu ununun tavuk köfte yapımında kullanımı. Adyütayam. 7(1), 23-32.

Kılınççeker, O., Hepsağ, F., \& Kurt, S. (2015). The effects of lentil and chickpea flours as the breading materials on some properties of chicken meatballs during 
frozen storage. Journal of food Sciences and Technology, 52(1), 580-585.

Kurt, Ş., \& Kılınççeker, O., (2012). The Effects of cereal and legume flours on the quality characteristics of beef patties. Kafkas Üniversitesi Veteriner Fakültesi Dergisi. 18(5), 725-730.

Mansour, E.H., \& Khalil, A.H., (1997). Characteristics of low-fat beef burger as influenced by various types of wheat fibers. Food Research International, 30 (34), 199-205.
Petracci, M., Bianchi, M., Mudalal, S., \& Cavani, C. (2013). Functional Ingredients for poultry meat products. Trends in Food Sciences and Technology, 33(1), $27-$ 39.

Sayar, S., \& Karataş, S.Ç., (2017). Nohutta tane (tohum) kabuğunun tüm tanenin fiziksel, kimyasal ve beslenme özellikleri üzerine etkisi. Gıda, 42(4), 468-476.

Soltanizadeh, N., \& Ghiasi-Esfahani, H., (2015). Qualitative improvement of low meat beef burger Using Aloe vera. Meat Science, 99(1), 75-80. 